\title{
PESANTREN DAN KEPEMIMPINAN KIAI: STUDI KASUS DI PONDOK PESANTREN MAMBAUS SHOLIHIN GRESIK (1980-2020)
}

\author{
Mahfud Ifendi \\ Sekolah Tinggi Agama Islam Sangatta Kutai Timur, Indonesia \\ Email: mahfudzifindi@gmail.com
}

Dikirim:29 Mei 2020 | Direvisi: 28 Juni 2020 | Dipublikasikan: 31 Juli 2020

\begin{abstract}
Abstraksi: Pesantren merupakan sebuah lembaga pendidikan Islam yang mampu bertahan dari terpaan badai perubahan dan era globalisasi yang telah terjadi, sehingga sampai saat ini dapat survive, masih konsisten bertahan dengan segala disiplin keilmuannya dan ciri khas lainnya. Eksistensi pesantren yang dari kemunculannya hingga dewasa ini tentulah ada hubungannya dengan kepemimpinan di dalamnya. Dalam pengelolaan pesantren membutuhkan sebuah pola atau gaya kepemimpinan dari seorang tokoh sentral kiai itu sendiri untuk mengembangkan pesantrennya. Bagaimana sebuah pesantren akan selalu berdiri kokoh di tengah pergumulan persaingan dunia yang semakin kompetitif ini, maka di dalam kepemimpinannyalah semua dapat dikelola dan ditentukan. Artikel ini bertujuan menganalisis gaya kepemimpinan KH. Masbuhin Faqih di pondok pesantren Mambaus Sholihin Gresik. Penelitian ini menggunakan pendekatan kualitatif, teknik pengumpulan data menggunakan teknik wawancara, observasi dan dokumentasi. Hasil penelitian menunjukkan bahwa KH. Masbuhin Faqih merupakan salah seorang pemimpin yang kharismatik, demokratis dan dalam keadaan tertentu dapat menjadi seorang yang otoriter. Tiap-tiap kiai, penulis meyakini bahwa di dalam kepemimpinannya pasti berbeda satu sama lain. Hal ini bisa dipengaruhi oleh faktor genealogi, kepribadian, pendidikan, lingkungan, geografi dan lain sebagainya.

Kata kunci: Pesantren; kepemimpinan; kharismatik.
\end{abstract}

\section{Pendahuluan}

Era globalisasi memang sarat dengan kemajuan ilmu pengetahuan dan teknologi. Dewasa ini teknologi sudah masuk di berbagai lini kehidupan masyarakat, baik dalam kehidupan sosial masyarakat, budaya, dan pendidikan, termasuk pesantren. Hal ini menyebabkan masyarakat dengan cepat pula meminta berbagai tuntutannya, namun demikian fenomena sekarang ini bukan berarti mengatakan bahwa pesantren di zaman dulu tidak dituntut dengan berbagai macam skill dan ketrampilan, pesantren di waktu dulu juga dituntut dengan berbagai kebutuhan dari masyarakat, akan tetapi tuntutannya jauh lebih banyak sekarang jika dibandingkan di zaman dahulu. ${ }^{1}$ Dalam rangka menghadapi tuntutan masyarakat seperti di atas, lembaga pendidikan termasuk pondok pesantren haruslah bersifat fungsional, sebab lembaga pendidikan sebagai salah satu wadah yang

\footnotetext{
1 M. Sulton dan Moh. Khusnuridlo, Manajemen Pondok Pesantren Dalam Perspektif Global (Yogyakarta: LaksBang PRESSindo, 2006), 1.
} 
dalam masyarakat biasa disebut sebagai 'pintu gerbang' dalam menghadapi tuntutan masyarakat, ilmu pengetahuan dan teknologi yang terus mengalami perubahan. ${ }^{2}$

Dalam menghadapi era globalisasi pondok pesantren dituntut lentur tanpa menghilakan karakteristik utamanya, yaitu kemampuan di bidang ilmu-ilmu agama. Dalam pertumbuhan dan perkembangan pondok pesantren terdapat beberapa titik kritis yang perlu dicermati, sebab secara langsung atau pun tidak langsung akan berpengaruh terhadap pertumbuhan dan perkembangan pondok pesantren itu sendiri. Sesuai dengan prinsip pondok pesantren al mubafadbotu 'ala al-qadiimi shaalih, wa al-akhdzu bi al-jadid al-ashlah (menjaga tradisi lama yang baik dan mengambil tradisi baru yang lebih baik). ${ }^{3}$

Dasar konstitusional pendidikan pesantren adalah pasal 26 ayat (1) dan ayat (4) undangundang Nomor 20 Tahun 2003 tentang Sistem Pendidikan Nasional. Pada pasal 1 disebutkan bahwa "Pendidikan nonformal diselenggarakan bagi warga masyarakat yang memerlukan layanan pendidikan yang berfungsi sebagai pengganti, penambah, dan/atau pelengkap pendidikan formal dalam rangka mendukung pendidikan sepanjang hayat". Selanjutnya, pada pasal 4 dinyatakan “ Satuan pendidikan nonformal terdiri atas lembaga kursus, lembaga pelatihan, kelompok belajar, pusat kegiatan belajar masyarakat, dan majelis taklim, serta satuan pendidikan yang sejenis". ${ }^{4}$

Sedangkan dasar teologis pesantren adalah ajaran Islam yakni bahwa melaksanakan pendidikan agama merupakan perintah dari Tuhan dan merupakan Ibadah kepada-Nya, dasar yang dipakai adalah al-Qur'an sebagaimana disebutkan dalam surat At-Taubah ayat 122:

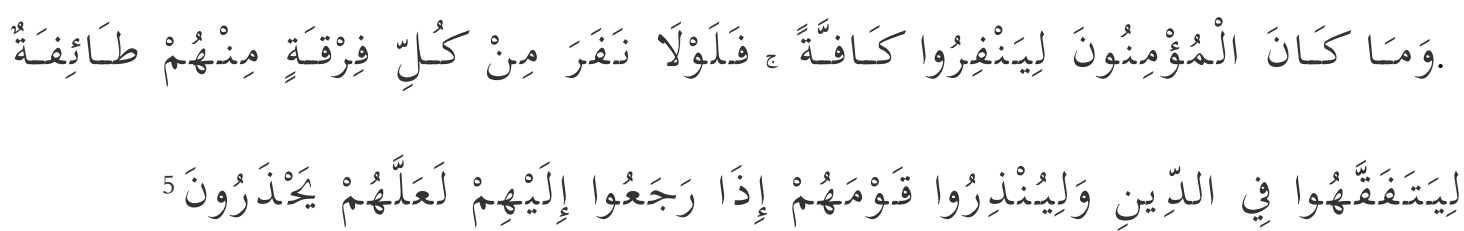

Artinya: Tidak sepatutnya bagi mukminin itu pergi semuanya (ke medan perang). Mengapa tidak pergi dari tiap-tiap golongan di antara mereka beberapa orang untuk memperdalam pengetahuan mereka tentang agama dan untuk memberi peringatan kepada kaumnya apabila mereka telah kembali kepadanya, supaya mereka itu dapat menjaga dirinya. ${ }^{6}$

\footnotetext{
2 Ibid., 1.

3 Zaini Hafidh, Badrudin "Pesantren dan Kemandirian Perekonomian: Studi tentang Kewirausahaan di Pondok Pesantren ArRisalab Cijantung IV Ciamis dalam "Manageria: Jurnal Manajemen Pendidikan Islam” Volume 3, Nomor 2, November 2018/1440, 29.

${ }^{4}$ Undang-Undang R.I. Nomor 20 Tabun 2003 Tentang Metode Pendidikan Nasional dan Peraturan Pemerintab R.I. Tabun 2010

Tentang Penyelenggaraan Pendidikan serta Wajib Belajar (Bandung: Citra Umbara, 2012), 38.

${ }^{5}$ Al-Qur'an 9: 122

${ }^{6}$ Kementerian Agama RI, al-Qur'an dan Terjemahnya (Jakarta : PT. Lentera Abadi,2010), 164.
} 
Sudah menjadi common sense bahwa pesantren lekat dengan figur kiai (atau Buya di Sumatera Barat, Ajengan di Jawa Barat, Bendoro di Madura, dan tuan guru di Lombok). Kiai dalam pesantren merupakan figur yang sentral, otoritatif, demokratik, laizzes fair, paternalistic, tradisionalis dan pusat seluruh kebijakan dan perubahan. Hal ini erat kaitannya dengan dua faktor berikut. Pertama, kepemimpinan yang tersentralisasi pada individu yang bersandar pada kharisma serta hubungan yang bersifat paternalistik. Kebanyakan pesantren menganut pola "serba mono", mono manajemen dan mono administrasi, sehingga tidak ada delegasi kewenangan ke unit-unit kerja yang ada dalam organisasi. Kedua, kepemilikan pesantren bersifat individual (atau keluarga), bukan komunal. Otoritas kiai sebagai pendiri sekaligus pengasuh pesantren sangat besar dan tidak bisa diganggu gugat. Faktor nasab (keturunan) juga kuat sehingga kiai bisa mewariskan kepemimpinan pesantren kepada anak (istilahnya putra mahkota) yang dipercaya tanpa ada komponen pesantren yang berani memprotes. Sistem alih kepemimpinan di pesantren seperti inilah yang kerapkali mengundang sindiran bahwa pesantren seperti halnya dengan sebuah "kerajaan kecil".?

Pesantren, sebagai institusi pendidikan asli Indonesia yang lebih tua dari Indonesia itu sendiri, adalah 'legenda hidup' yang masih eksis hingga hari ini. Dalam pandangan Nurcholis Madjid, eksistensi pesantren ini lebih dikarenakan tidak hanya identik dengan makna keIslaman, tetapi karakteristik eksistensialnya mengandung arti keaslian Indonesia (Indigenous). ${ }^{8}$ Eksistensi dan kiprah pondok pesantren dalam masyarakat senilai dan sebangun dengan kemampuannya dalam menjawab kebutuhan masyarakat kontemporer, sehinggas tumbuh dan berkembangnya mengikuti tuntutan dan dinamika lingkungan. Dalam arti kegiatan pengembangan yang dilakukan oleh pesantren merupakan keharusan agar dapat terus eksis di dalam perkembangan zaman yang kian cepat dan mengglobal. ${ }^{9}$

Di dalam salah satu tulisan Zamakhsyari Dhofier dinyatakan bahwa unsur-unsur dasar yang membentuk pesantren adalah kiai, masjid, asrama, santri, dan kitab kuning. ${ }^{10}$ Pesantren itu terdiri dari lima elemen pokok, yaitu ; kiai, santri, masjid, pondok, dan pengajaran kitab-kitab klasik. Kelima elemen tersebut merupakan ciri khusus yang dimiliki pesantren dan membedakan pendidikan pondok pesantren dengan lembaga pendidikan dalam bentuk lain. Sekalipun kelima elemen ini saling menunjang eksistensi sebuah pesantren, tetapi kyai memainkan peranan yang begitu sentral dalam dunia pesantren.

Keberadaan seorang kyai dalam sebuah lingkungan pesantren laksana jantung bagi kehidupan manusia. Intensitas kyai memperlihatkan peran yang otoriter disebabkan karena kyailah

\footnotetext{
${ }^{7}$ M. Sulthon dan Moh. Khusnuridlo, Manajemen Pondok Pesantren, 31.

${ }^{8}$ Abdul Chalik, Kiprah Tradisionalis Yang Tersisih (Yogyakarta: Inter Pena, 2011), XI.

${ }^{9}$ Abd. Chayyi Fanany, Pesantren Anak Jalanan (Surabaya: Alpha, 2008), 88.

${ }^{10}$ Zamakhsyari Dhofier, Tradisi Pesantren: Studi Tentang Pandangan Hidup Kiai (Jakarta: LP3ES, 1982), 44.
} 
perintis, pendiri, pengelola, pengasuh, pemimpin, dan bahkan juga pemilik tunggal sebuah pesantren. Oleh sebab alasan ketokohan kyai di atas, banyak pesantren akhirnya bubar lantaran ditinggal wafat kyainya. Sementara kyai tidak memiliki keturunan yang dapat melanjutkan perjuangannya.

Model pendidikan pesantren yang full day of education menjadi pilihan pengasuh demi memaksimalisasi dan efektivitas pengintegrasian nilai-nilai dan ajaran agama Islam. Visi besar kiai dalam hal ini ialah akan lahir generasi-generasi bermutu yang amanah. Kiai tidak saja bertanggung jawab untuk membimbing santri dari tidak tahu menjadi tahu, akan tetapi juga membiasakan praktik hidup yang selaras dan sesuai dengan ajaran dan nilai Islam. ${ }^{11}$ Kesederhanaan, kemandirian, keistiqomahan, ketekunan, ketawadhu'an, dan berbagai disiplin nilai-nilai ajaran islam harus selalu ditampilkan oleh sang kiai, agar menjadi role model bagi seluruh santri yang menimba ilmu di sebuah pesantren.

Setiap lembaga pendidikan, termasuk pesantren dituntut untuk memberikan pelayanan yang sebaik mungkin kepada masyarakat. Agar dapat melakukan hal tersebut dengan baik, pesantren perlu dukungan sistem manajemen yang baik agar bisa menyesuaikan diri dengan tantangan modernitas yang ada. ${ }^{12}$ Beberapa ciri sistem manajemen yang baik adalah adanya pola pikir yang teratur (administrative thinking), pelaksanaan kegiatan yang teratur (administrative behavior), dan penyikapan terhadap tugas-tugas kegiatan secara baik (administrative attitude)..$^{13}$

Pada prinsipnya, setiap pengelolaan suatu lembaga pendidikan mensyaratkan adanya gaya pemimpin dan kepemimpinan yang khas. Misalnya, dalam era reformasi sekarang ini dibutuhkan kepemimpinan yang mampu memberdayakan masyarakat pesantren dengan tanpa mengorbankan ciri khas atau kredibelitas pengasuh pesantren. ${ }^{14}$

Tentu yang dimaksud adalah seorang pemimpin dengan gaya kepemipinannya yang bertujuan untuk memberikan pelayanan terbaik kepada santri dan masyarakat di sekitarnya serta berjuang demi menegakkan agama Allah SWT.

Masalah kepemimpinan (leadership) merupakan pembahasan yang menarik, karena ia adalah salah satu faktor penting yang mempengaruhi berhasil atau gagalnya suatu organisasi. Memang harus diakui bahwa suatu organisasi akan dapat mencapai tujuannya manakala sumber permodalan mencukupi, struktur organisasinya akurat, dan tenaga terampilnya tersedia. Sekalipun faktor tersebut berkaitan erat dengan berhasil atau tidaknya organisasi, namun kepemimpinan juga merupakan faktor penting yang pantas dipertimbangkan. Tanpa pemimpin yang baik, maka roda organisasi tidak akan berjalan dengan lancar. ${ }^{15}$

\footnotetext{
${ }^{11}$ Ibnu Hajar, Kiai di Tengah Pusaran Politik antara Petaka dan Kuasa (Jogjakarta :IRCiSoD, 2009), 45.

12 Gatot Krisdianto, Muflikha, Muflikha, Elly Elvina Sahara, Choirul Mahfud, "Sistem Pendidikan Pesantren dan Tantangan Modernitas". Tarbawi: Jurnal Ilmu Pendidikan, Vol. 15 Nomor 1 (July 2019), 11-21.

${ }^{13}$ M. Sulthon Masyhud dan Moh. Khusnuridlo, Manajemen Pondok Pesantren (Jakarta: Diva Pustaka Press, 2005$), 23$.

${ }^{14} \mathrm{Ibid}, 25$.

${ }^{15}$ Sukamto, Kepemimpinan Kiai Dalam Pesantren (Jakarta: PT Pustaka LP3ES, 1999), 19.
} 
Demikian halnya para pemimpin heroik seperti Washington, Napoleon, Roosevelt, Jawaharlal Nehru, dan sebagainya telah membuktikan kepada dunia bahwa ia telah membentuk dirinya menjadi pemimpin dunia. Semuanya menjadi masyhur karena keahliannya dalam memainkan perang penting untuk membantu bangsa dan negaranya mencapai tujuan. ${ }^{16}$ Soekarno dan Hatta berhasil memproklamasikan kemerdekaan Indonesia di tengah suasana perjuangan yang sangat berat. Hal ini disebabkan oleh kemahirannya dalam mengaplikasikan ilmu dan seni memimpin dalam bentuk sikap dan perilaku. ${ }^{17}$

Jika seorang pemimpin kurang kreatif dan tidak dinamis maka pesantren yang dipimpinnya pun akan melempem. Umumnya hal ini juga menentukan bagaimana pesantren itu memimpin anggota dan pekerjaannya. Pemimpin harus mengutamakan tugasnya yaitu seorang pemimpin harus bekerja dengan yang lain ${ }^{18}$, menggerakkan bawahannya, memberikan motivasi, siap menjadi pelopor, pemimpin harus menjadi seorang yang berfikir secara analitis dan konseptual, seorang pemimpin harus dapat menyusun tugas, menjalankan tugas, dan mengevaluasi untuk mencapai sebuah tujuan. Seorang pemimpin juga harus tanggung jawab yaitu berkewajiban menyelesaikan tugas-tugasnya dan mempertanggungjawabkan kepada atasan atau kepada orang yang mendelegasikan wewenang mengenai hasil yang telah dicapai, serta membina hubungan yang harmonis, baik dengan atasannya maupun dengan para bawahannya. Jadi pemimpin harus mengadakan komunikasi ke atas dan ke bawah, baik komunikasi formal maupun komunikasi informal. ${ }^{19}$ Komunikasi formal merupakan jalur komunikasi resmi dengan rantai komando atau hubungan tugas dan tanggung jawab yang jabatannya dalam organisasi. Sedangkan komunikasi informal merupakan jalur komunikasi tidak resmi di lingkungan maupun di luar organisasi, tetapi masih berkaitan dengan fungsi tidak langsung para pemimpin organisasi, seperti internet. ${ }^{20}$

Menurut konsep Islam, semua orang adalah pemimpin. Karena itu, setiap orang harus mempertanggungjawabkan perbuatannya kepada sesamanya semasa di dunia dan kepada Tuhannya kelak. Hal ini berdasarkan hadis Nabi sebagai berikut:

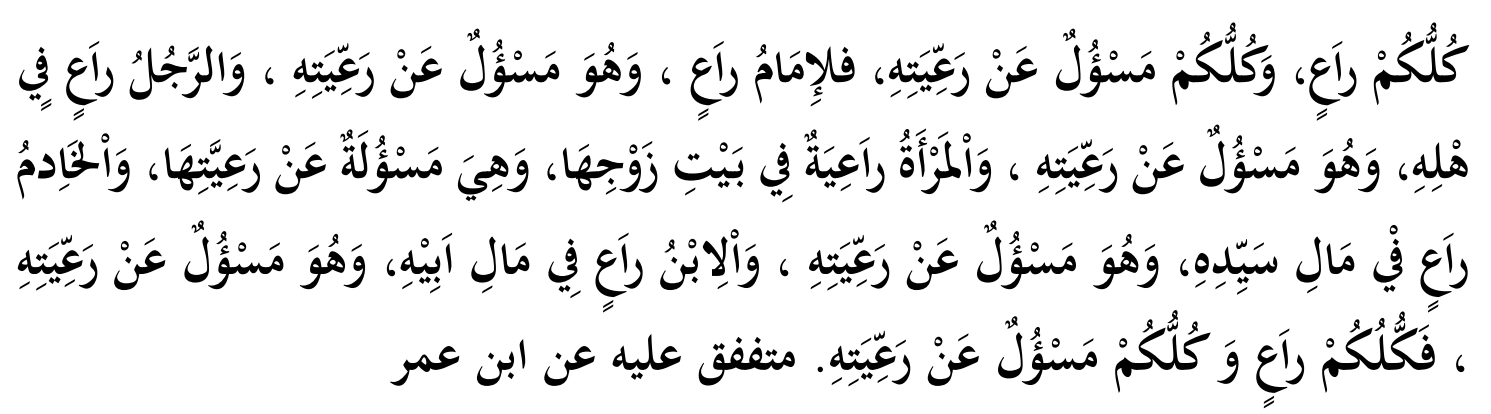

\footnotetext{
${ }^{16}$ Siswanto, Pengantar Manajemen (Jakarta: PT. Bumi Aksara, 2013), 153.

${ }^{17}$ Ibid, 153.

${ }^{18}$ Veithzal Rivai, Pemimpin dan Kepemimpinan dalam Organisasi (Jakarta: PT Raja Grafindo Persada, 2005), 17.

${ }^{19}$ Malayu S.P. Hasibuan, Manajemen (Jakarta: Bumi Aksara, 2005), 42.

${ }^{20}$ Manahan P. Tampubolon, Perilaku Keorganisasian (Bogor: Ghalia Indonesia, 2004), 109.
} 
Artinya :"kalian semua adalah pemimpin, dan akan dimintai pertanggujawabannya, Seorang imam adalah pemimpin dan akan dimintai pertanggungjawabannya, seorang laki-laki adalah pemimpin terhadap kepemimpinannya dalam keluarga, seorang wanita adalah pemimpin di dalam rumah suaminya, pembantu adalah pemimpin dalam menjaga harta tuannya dan akan dimintai pertanggungjawabannya, anak adalah pemimpin dalam menjaga harta orang tuanya, dan semuanya akan dimintai pertanggungjawabannya." ${ }^{21}$

Namun demikian, yang dimaksud pemimpin dalam tulisan ini bukanlah setiap warga masyarakat seperti ungkapan hadits di atas, melainkan figur kiai, pengasuh pondok pesantren yang menjadi tokoh kunci santri.

Seperti teori yang telah terkemuka di atas, bahwa begitu pentingnya fundraising, tenaga yang terampil, serta struktur yang akurat, kepemimpinan juga merupakan komponen penting yang bisa menentukan berhasil atau tidaknya sebuah lembaga atau organisasi. Dalam fokus artikel ini, penulis akan mencoba mengupas tuntas bagaimana gaya kepemimpinan seorang kiai yang cukup memiliki popularitas yang tinggi di wilayah Gresik, yang dengan kesungguhannya telah memimpin pesantren menjadi begitu pesat perkembangannya.

Oleh karena itu, bagaimana gaya kepemimpinan KH. Masbuhin Faqih ini dapat membawa perkembangan pesantren yang dipimpin dapat berkembang secara cepat, tak heran dalam jangka waktu 40 tahun ini, pesantren yang dipimpin beliau sekarang sudah memiliki beberapa cabang di berbagai daerah seperti di Jawa, Riau, Bali, dan Maluku Tengah. Melihat berbagai perkembangan ini, tentunya memerlukan sebuah gaya kepemimpinan yang dinamis, tegas, dan penuh dengan inovasi dalam mengelola perkembangan pesantren. Oleh karena itu terkait gaya kepemimpinan KH Masbuhin Faqih akan menjadi fokus dalam penulisan artikel ini.

\section{Kajian Teoretik}

\section{Makna Kepemimpinan}

Dalam menjalankan organisasi diperlukan seorang pemimpin yang rasional berkompetensi mengarahkan kegiatan organisasi dalam mencapai tujuan. Seorang pemimpin yang berkemampuan mempengaruhi perilaku orang lain ke arah tujuan tertentu sebagai indikator hasilnya. ${ }^{22}$ Selanjutnya sebagaimana pemahaman awal dikemukakan beberapa pendapat para pakar dan ahli perilaku organisasi antara lain, Robert G. Owens, sebagaimana yang dikutip oleh Ismail Nawawi Uha, mengartikan kepemimpinan sebagaimana keterlibatan yang dilakukan secara sengaja untuk mempengaruhi orang sebagaimana definisi kepemimpinan yang merupakan kemauan dan keterlibatan serta latihan untuk mempengaruhi prilaku orang lain. ${ }^{23}$

\footnotetext{
${ }^{21}$ Sayyid Ahmad Hasyim, Mubtar al-Hadits an-Nabawiyyah (Jakarta: al Haramain Jaya Indonesia, 2005), 130.

${ }^{22}$ Ismail Nawawi Uha, Perilaku Organisasi (Jakarta: CV. Dwiputra Pustaka Jaya, 2010), 247.

${ }^{23}$ Ibid., 247
} 
Makna kepemimpinan secara umum menurut Halida yaitu kemampuan untuk mempengaruhi suatu kelompok untuk pencapaian tujuan. ${ }^{24}$ Dalam pengertian ini sangat luas karena tidak dijelaskan bagaimana seseorang mempengaruhi kelompoknya, yang terpenting adalah bagaimana sebuah tujuan dapat dicapai. Hal ini menunjukkan sebuah pengertian secara umum atau sangat luas batasanannya. Senada dengan Halida, Djarkasih mengatakan bahwa kepemimpinan adalah suatu upaya penggunaan jenis pengaruh, bukan paksaan (concoersive) untuk memotivasi orangorang mencapai tujuan tertentu. ${ }^{25}$ Demikian halnya dengan Siswanto mengatakan bahwa kepemimpinan adalah sebagai proses pengarahan dan mempengaruhi aktifitas yang dihubungkan dengan tugas dari para anggota kelompok. ${ }^{26}$

Di sisi lain pengetian kepemimpinan secara rinci diungkapkan oleh Muhammad Karim yang menyatakan bahwa kepemimpinan adalah proses perilaku untuk menenangkan hati, pikiran, emosi dan perilaku orang lain untuk berkontribusi terhadap terwujudnya visi. ${ }^{27}$ Sekilas memang pengertian yang diungkapkan Karim memang sederhana, namun jikalau kita bahas satu per satu tentunya akan cukup panjang lebar. Karim menjelaskan lebih detail bahwa kepemimpinan bukan hanya mempengaruhi seseorang, namun lebih dari itu Karim mengatakan bahwa kepemimpinan adalah proses menenangkan hati, pikiran, dan perilaku. Tentu pengertian ini lebih detail daripada pengertian menurut para ahli di atas sebelumnya.

Senada dengan Muhammad Karim, Khoirul Arif berpendapat bahwa kepemimpinan merupakan aspek dinamis dari pemimpin, yaitu mengacu pada tindakan-tindakan atau perilaku yang ditampilkan dalam melakukan serangkaian pengelolaan, pengaturan, dan pengarahan untuk mencapai tujuan..$^{28}$ Arif menyebutkan bahwa kepemimpinan bukan sekedar mempengaruhi, namun bagaimana semuanya dikelola, diatur, dan diarahkan untuk mencapai tujuan yang diinginkan.

Hubungan antara pemimpin dan mereka yang dipimpin bukanlah hubungan satu arah tetapi senantiasa harus terdapat adanya antar hubungan (interaction). Bahwa seorang pemimpin harus dapat mempengaruhi kelompoknya, jelas karena apabila ia tidak mampu melakukannya maka berarti dalam hal ini ia tidak dapat menjalankan tugasnya sebagai pemimpin yang baik. ${ }^{29}$

Dari definisi-definisi yang telah dikemukakan di atas dapatlah kita menyimpulkan bahwa kepemimpinan itu merupakan suatu kemampuan yang melekat pada diri seorang yang memimpin. Adakalanya kepemimpinan seorang pemimpin sangat menonjol atau berkembang pada periode tertentu, sedangkan pada periode lain hal tersebut akan memudar. Kepemimpinan bukan hanya

\footnotetext{
${ }^{24}$ Halida, Prinsip-Prinsip Perilaku Organisasi (Jakarta: PT. Gelora Aksara Pratama, 1999), 163.

${ }^{25}$ Djarkasih, Organisasi (Jakarta: PT. Gelora Aksara Pratama, 1997), 334.

${ }^{26}$ Siswanto, Pengantar Manajemen, 153.

${ }^{27}$ Muhammad Karim, Pemimpin Transformatif di Lembaga Pendidikan Islam (Malang: UIN-Maliki Press, 2010), 14.

${ }^{28}$ M. Khoirul Arif, Manajemen Pesantren (Yogyakarta: Pustaka Pesantren, 2005), 88.

${ }^{29}$ Winardi, Kepemimpinan dalam Manajemen (Jakarta: PT Rineka Cipta, 1990), 56.
} 
sekedar berebut pengaruh, akan tetapi bagaimana kepemimpinan itu dapat mengatur, mengelola, mengarahkan, menenangkan hati, pikiran, emosi, dan perilaku yang dipimpin agar mereka dengan sepenuh hati menjalankan tugasnya demi tercapainya sebuah tujuan bersama.

\section{Tipologi Kepemimpinan}

Pendekatan (approach) yang dapat kita gunakan untuk mengerti suksesnya kepemimpinan, yakni kita memusatkan perhatian pada apa yang dilakukan oleh pemimpin tersebut; jadi gayanya. Ada macam-macam istilah yang digunakan orang untuk menerangkan approach pada umumnya yang dipergunakan oleh para pemimpin dalam situasi-situasi kemanusiaan. ${ }^{30}$ Meskipun belum terdapat kesepakatan bulat tentang tipologi kepemimpinan yang secara luas dikenal dewasa ini, setidaknya ada lima tipe kepemimpinan yang diakui keberadaannya.

a. Tipe Otokratif

Dilihat dari segi persepsinya, seorang pemimpin otokratik atau otoriter adalah seorang pemimpin yang egois. Egoismenya sangat besar akan mendorongnya memutarbalikkan kenyataan yang sebenarnya sehingga sesuai dengan apa yang secara subjektif diinterpretasikan sebagai kenyataan. Egonya yang sangat besar menumbuhkan dan mengembangkan persepsinya bahwa tujuan organisasi identik dengan tujuan pribadinya dan oleh karenanya organisasi diperlakukan sebagai alat untuk mencapai tujuan pribadi tersebut.

Dengan egoisme yang besar demikian, seorang pemimpin yang otokratik melihat peranannya sebagai sumber segala sesuatu dalam kehidupan organisasi seperti kekuasaan yang tidak perlu dibagi dengan orang lain dalam organisasi. Suatu tindakan akan dinilai benar jika tindakan itu mempermudah tercapainya tujuan dan semua tindakan yang menjadi penghalang akan dipandangnya sebagai sesuatu yang tidak baik dan dengan demikian akan disingkirkannya, apabila perlu dengan tindakan kekerasan. ${ }^{31}$

b. Tipe Paternalistik

Kepemimpinan yang paternalistik dicirikan oleh suatu pengaruh yang bersifat kebapakan dalam hubungan antar manajer dengan pesantren. Tujuannya adalah untuk melindungi dan menberikan arah, tindakan, dan perilaku ibarat peran seorang bapak kepada anaknya. ${ }^{32}$

Persepsi seorang pemimpin yang paternalistik tentang peranannya dalam kehidupan organisasi dapat dikatakan diwarnai oleh harapan para pengikutnya. Harapan itu pada umumnya berwujud keinginan agar pemimpin mereka mampu berperan sebagai bapak yang bersifat melindungi dan yang layak dijadikan sebagai tempat bertanya dan untuk memperoleh petunjuk.

\footnotetext{
${ }^{30}$ Ismail Nawawi Uha, Perilaku Organisasi, 264.

${ }^{31}$ Sondang P. Siagian, Teori dan Praktik. Kepemimpinan (Jakarta: PT. Rineka Cipta, 1994), 31.

${ }^{32}$ Siswanto, Pengantar Manajemen, 159.
} 
Ditinjau dari segi nilai organisasi yang dianut, biasanya pemimpin yang paternalistik mengutamakan kebersamaan. Nilai demikian biasanya terungkap dalam kata-kata seperti "seluruh anggota organisasi adalah anggota satu keluarga besar" dan pernyataan lain yang sejenisnya. Ada pandangan yang mengatakan bahwa di mata seorang pemimpin yang paternalistik, para bawahannya belum dewasa dalam cara bertindak dan berfikir sehingga memerlukan bimbingan dan tuntutan terus-menerus. ${ }^{33}$

c. Tipe Kharismatik

Pemimpin kharismatik adalah pemimpin yang ide/gagasan, konsep, teori, suasana batin, dan perilakunya meyakinkan orang lain. Dalam banyak kasus, yang kemudian disimpulkan dalam banyak teori tentang kepemimpinan menunjukkan bahwa pemimpin kharismatik seringkali muncul pada saat terjadi kekacauan kehidupan, baik pada skala individu maupun sosial. Skala individu berupa kecemasan, sikap pesimis, dan tumpulnya nalar kritis, sedangkan skala sosial berupa kekacauan, politik, ekonomi, sosial, pendidikan, agama, dan krisis-krisis lainnya. ${ }^{34}$

Pada saat individu lain mengalami krisis kebatinan semisal depresi tentang kehidupan, kecemasan berlebihan, pesimis tidak sadar, ia tampil sebagai pencerah atas itu semua. Sikap mengorbankan diri, berani merugi, mengambil resiko untuk kepentingan orang lain adalah ciri utama dari pemimpin kharismatik, ia bahkan sengaja untuk memuliakan dan selalu mempermudah urusan orang lain. Kepemimpinan kharismatik merupakan hasil perpaduan antara perilaku memberikan perhatian individu dan gagasan yang cemerlang. Pemimpin karismatik sangat sensitif dalam merasakan kesulitan orang lain dan segera berbuat sesuatu untuk menolongnya. ${ }^{35}$

d. Tipe Laisser faire

Berdasarkan teori ini, seorang pemimpin memberikan kebebasan seluas-luasnya kepada pengikutnya dalam hal menentukan aktifitas mereka. Pendekatan ini merupakan kebalikan dari tipe otokratik. ${ }^{36}$

Dapat dikatakan bahwa persepsi seorang pemimpin yang laissez fair tentang peranannya sebagai pemimpin berkisar pada pandangan bahwa pada umumnya organisasi akan berjalan lancar dengan sendirinya karena para anggota organisasi terdiri dari orang-orang yang sudah dewasa yang mengetahui apa yang menjadi tujuan organisasi. Tipe pemimpin seperti ini

\footnotetext{
${ }^{33}$ Sondang P. Siagian, Teori dan Praktik. Kepemimpinan., 36.

${ }^{34}$ Muhammad Karim, Pemimpin Transformatif di Lembaga Pendidikan Islam 17.

${ }^{35}$ Ibid, 19.

${ }^{36}$ Winardi, Kepemimpinan dalam Manajemen, 64.
} 
cenderung memilih peranan yang pasif dan membiarkan organisasi berjalan menurut temponya sendiri tanpa banyak mencampuri bagaimana organisasi harus dijalankan dan digerakkan.

Bertitik tolak dari nilai-nilai organisasi demikian, sikap seorang pemimpin laissez fair dalam memimpin organisasi dan para bawahannya biasanya adalah sikap permisif, dalam artian bahwa para anggota organisasi boleh saja bertindak sesuai dengan keyakinan dan bisikan hati nuraninya asal saja kepentingan bersama tetap terjaga dan tujuan organisasi tetap tercapai. ${ }^{37}$

e. Tipe Demokratik

Pada kepemimpinan demokratik, manajer beranggapan bahwa ia merupakan bagian integral yang sama sebagai elemen pesantren dan secara bersamaan seluruh elemen tersebut bertanggung jawab terhadap pesantren. Oleh karena itu, agar seluruh bawahan merasa turut bertanggung jawab maka mereka harus berpartisipasi dalam setiap aktifitas perencanaan, pelaksanaan, dan evaluasi. Setiap individu bawahan merupakan potensi yang berharga dalam usaha merealisasikan tujuan. ${ }^{38}$

Baik dalam kalangan ilmuan maupun praktisi terdapat kesepakatan bahwa tipe pemimpin yang paling ideal dan paling didambakan adalah pemimpin yang demikratik. Memang umum diakui bahwa pemimpin demokratik tidak selalu merupakan pemimpin yang paling efektif dalam kehidupan organisasi karena ada kalanya, dalam hal bertindak dan mengambil keputusan, bisa terjadi keterlambatan sebagai konsekuensi keterlibatan para bawahan dalam proses pengambilan keputusan tersebut.

Tetapi dalam berbagai kelemahannya, pemimpin yang demokratik tetap dipandang sebagai pemimpin terbaik karena kelebihan-kelebihannya mengalahkan kekurangankekurangannya. Pemimpin demokratik biasanya memandang peranannya selaku koordinator dan integrator dari berbagai unsur dan komponen organisasi sehingga bergerak sebagai suatu totalitas. ${ }^{39}$

Seorang pemimpin yang demokratik dihormati dan disegani dan bukan ditakuti karena perilakunya dalam kehidupan organisasi perilakunya mendorong para bawahannya menumbuhkan dan mengembangkan daya inovasi dan kreatifitasnya. Jika terjadi kesalahan, pimpinan yang demokratik berada di samping bawahan yang berbuat kesalahan itu bukan untuk menindak atau menghukumnya, melainkan meluruskannya sedemikan rupa sehingga bawahan tersebut belajar dari kesalahannya itu dan demikian menjadi anggota organisasi yang lebih bertanggung jawab. ${ }^{40}$

\footnotetext{
${ }^{37}$ Sondang P. Siagian, Teori dan Praktik Kepemimpinan., 39.

${ }^{38}$ Siswanto, Pengantar Manajemen, 158.

${ }^{39}$ Sondang P. Siagian, Teori dan Praktik Kepemimpinan, 40.

${ }^{40} \mathrm{Ibid}, 43$.
} 


\section{Teori Kelahiran Kepemimpinan}

Teori kepemimpinan membicarakan bagaimana seseorang menjadi pemimpin, atau bagaimana timbulnya seorang pemimpin. Untuk mendapatkan gambaran yang lebih jelas mengenai teori-teori kepemimpinan, maka berikut ini akan diuraikan beberapa teori kepemimpinan.

a. Teori Kelebihan

Teori ini beranggapan bahwa seseorang akan menjadi pemimpin apabila memiliki kelebihan-kelebihan yang tidak dimiliki oleh orang lain. Pada dasarnya kelebihan tersebut adalah, pertama, kelebihan ratio, ialah kelebihan menggunakan daya pikiran, kelebihan dalam berorganisasi, serta pengambilan keputusan yang tepat dan cepat. Kedua, kelebihan rohaniah, berarti seorang pemimpin harus menunjukkan keagungan akhlak dan tingginya budi pekerti kepada para pengikutnya. Segala tindakan, ucapan serta ketetapanya harus menjadi suri tauladan bagi mereka. Ketiga, kelebihan badaniyah, seorang pemimpin hendaknya memiliki kesehatan badan yang lebih dari pada pengikutnya sehingga memungkinkan untuk bertindak dengan cepat. ${ }^{41}$

b. Teori Sifat

Pada dasarnya sama dengan teori kelebihan. teori ini menyebutkan bahwa seseorang dapat menjadi pemimpin yang baik apabila memiliki sifat-sifat yang lebih dari pada yang dipimpin. di samping memiliki kelebihan ratio, rohaniah, dan badaniyah, seorang pemimpin harus memiliki sifat-sifat yang positif, misalnya: adil, suka melindungi, percaya diri, penuh inisiatif, mempunyai daya tarik, energik, komunikatif dan kreatif.

\section{c. Teori Keturunan}

Teori ini menyatakan bahwa seseorang dapat memnjadi pemimpin karena keturunan atau warisan. Karena orang tuanya seorang pemimpin, maka anaknya otomatis aakan akan menjadi pemimpin menggantikan orang tuanya, seolah-olah seseorang menjadi pemimpin karena ditakdirkan.

\section{d. Teori Bakat}

Teori ini disebut juga teori ekologis, menyatakana bahwa pemimpin itu lahir karena bakatnya. ia menjadi pemimpin karena mempunyai bakat untuk menjadi pemimpin. Bakat kepemimpinan itu harus dikembangkan, misalnya dengan memberi kesempatan orang tersebut menduduki suatu jabatan.

\section{e. Teori Sosial}

Teori ini beranggapan bahwa setiap orang dapat menjadi pemimpin. Setiap orang mempunyai bakat untuk menjadi pemimpin asal dia diberi kesempatan. Setiap orang dapat dididik

\footnotetext{
${ }^{41}$ Veithzal Rivai, Pemimpin dan Kepemimpinan, 7.
} 
menjadi pemimpin karena masalah kepemimpinan bisa dipelajari, baik melalui pendidikan formal maupun melalui pengalaman praktik.

f. Teori Kharismatik

Seseorang menjadi pemimpin karena mempunyai kharisma (pengaruh) yang sangat besar. Kharisma itu didapat dari kekuatan yang maha kuasa. Pemimpin yang bertipe kharismatik biasanya memiliki daya tarik, dan pengaruh yang sangat besar.

\section{Metode Penelitian}

Penulisan artikel ini menggunakan pendekatan deskriptif kualitatif ${ }^{42}$, jenis penelitian lapangan, dengan tujuan data yang dihasilkan akan lebih menggambarkan realitas obyetif di lapangan dengan harapan hasil penulisan ini dapat mengungkap fenomena dan gejala serta mendeskripsikan secara menyeluruh dan mendalam tentang gaya kepemimpinan $\mathrm{KH}$. Masbuhin Faqih. Guna mendapatkan data dan informasi yang baik, maka penulis melakukan kegiatan wawancara secara mendalam terhadap beberapa informan, melakukan observasi dan mendokumentasikan berbagai informasi yang didapat. Penelitian ini dilaksanakan di Pondok Pesantren Mambaus Sholihin Jln. KH. Syafi'i No 07 kode pos 51161 desa Suci kecamatan Manyar kabupaten Gresik Jawa Timur.

\section{Temuan Penelitian dan Pembahasan}

\section{Gaya Kepemimpinan KH. Masbuhin Faqih di Pondok Pesantren Mambaus Sholihin}

Setiap pemimpin pasti memiliki gaya atau model yang melekat pada diri seorang pemimpin itu sendiri. Hal ini yang akan memberikan pengaruh atau tidaknya terhadap para bawahan atau perkembangan sebuah lembaga atau organisasi yang dipimpin. Berdasarkan observasi penulis dan olah data secara mendalam, maka di bawah ini akan penulis paparkan mengenai gaya kepemimpinan KH. Masbuhin Faqih.

Berbicara tentang perangai beliau KH Masbuhin Faqih adalah seorang yang sangat tawadhu' terhadap guru-guru beliau, tekun dan giat dalam hal menuntut ilmu hal ini sebagaimana diungkapkan oleh Ustadz Ahsan Ghozaliy:

\footnotetext{
42 Penelitian ini dilakukan untuk mempelajari secara intensif tentang fenomenologi, latar belakang, dan interaksi lingkungan dari unit-unit sosial yang menjadi subyek. Lihat Arifin Imron, Penelitian Kualitatif (Malang: Kalimadasa Pers, 1996), 19. Metode kualitatif sering digunakan untuk menghasilkan grounded theory yakni teori yang timbul dari data bahan dari hipotesis-hipotesis, atas dasar itu penelitian bersifat generating theory, seehingga teori yang dihasilkan berupa teori substantif. Ciri khas penelitian kualitatif tidak dapat dipisahkan dari pengamatan, namun peranan penelitilah yang menentukan keseluruhan skenarionya. Lihat . Riyanto, Metodologi Penelitian: Suatu Tinjauan Dasar (Surabaya: SIC, 2001), 15.
} 
"Beliau adalah seorang yang tawadhu', apalagi dengan para kyai atau guru, dan bahkan kepada putra-putra kyai serta keluarganya. Beliau adalah seorang yang pemurah, hangat, giat, tegas dalam kebenaran dan disiplin. Beliau sangat menjunjung tinggi akan nilai-nilai sopan santun kepada kyai/gurunya. Hal ini yang harus ditiru dari kyai Masbuhin oleh para santri, karena tidak sedikit santri yang pintar-pintar, namun mereka kurang sopan terhadap kyai/gurunya." 43

Senada dengan Ustadz. Ahsan Ghazaly, Ustadz. Nadiful Alim menjelaskan bahwa KH. Masbuhin adalah seorang yang tegas dan disiplin.

"Beliau adalah seorang yang sangat tegas dan disiplin dalam hal apapun. Contoh nyata yang saya alami dulu ketika ada santri yang melanggar bahasa ${ }^{44}$, maka secara tegas dan disiplin, beliau langsung menghukumnya." ${ }^{45}$

Lebih detail lagi, Ustadz. Abdul Ghofur menjelaskan bahwa beliau adalah sosok yang sangat disiplin terhadap waktu, keras, selalu menganjurkan kedisiplinan, pemurah dan pemaaf.

"KH. Masbuhin Faqih itu seseorang yang kharismanya luar biasa, disiplin waktu, keras, tegas terhadap belajar, selalu mengutamakan kedisiplinan, seorang yang pemurah, dermawan, dan mudah melupakan kesalahan orang lain. Dulu ketika saya masih nyantri di Langitan, dan diajar oleh beliau, suatu hari ada teman saya yang ramai saat beliau menerangkan pelajaran, seketika itu juga beliau langsung memukul teman saya, namun keesokan harinya beliau langsung menyapa dengan senyuman, ini artinya beliau langsung melupakan kesalahan orang lain, tidak memiliki perasaan dendam." 46

Sedangkan menurut Agus Moh. Najib menjelaskan bahwa ada sedikit perubahan tentang sifat keras beliau untuk saat ini. Seiring bertambahnya umur, sifat keras yang dulu melekat, kini kian pudar perlahan-lahan.

"Beliau memang seorang yang tegas, keras, disiplin dan suka memotivasi santri-santri. Ketika masih muda beliau sangat keras sekali dalam mendidik santri, namun seiring berjalannya waktu, seiring dengan bertambahnya umur, kekerasan beliau dalam mendidik santri sudah mulai menurun. Saat ini yang ditonjolkan dari beliau adalah sikap belas kasih terhadap para santri. Namun untuk kedisiplinan, sampai sekarang beliau masih tetap disiplin terhadap berbagai hal." ${ }^{, 7}$

\footnotetext{
43 Wawancara dengan Ust. Ahsan Ghazaly (menantu KH. Abdullah Faqih Langitan-Tuban)

44 Pondok pesantren Mambaus Sholihin Gresik ini merupakan pondok bahasa. Dalam artian, keseharian santri di sana menggunakan dwi bahasa (Arab dan Inggris). Jika ada santri yang ketahuan menggunakan bahasa daerah atau Indonesia, maka akan dikenai sanksi. Penggunaan bahasa Indonesia hanya teruntuk santri baru, baik dari Mts, MA maupun perguruan tinggi, itupun diberi waktu 6 bulan untukbelajar adaptasi menggunakan bahasa resmi pondok yang ada.

45 Wawancara dengan Ust. Nadhiful Alim (Guru MA Mambaus Sholihin)

46 Wawancara dengan Ust. Abdul Ghofur (Guru senior di Mts Mambaus Sholihin)

${ }^{47}$ Wawancara dengan Gus Moh. Najib (Menantu KH. Masbuhin Faqih)
} 
Berbicara tentang gaya kepemimpinan KH. Masbuhin Faqih, Moh. Najib menerangakan bahwa gaya beliau dalam memimpin adalah demokratis dan kharismatik.

"Masalah kepemimpinan, beliau adalah tipe pemimpin yang demokratis dan kharismatik. Dalam moment rapat apapun, beliau selalu meminta saran dan masukan kepada para pembimbing dan ustadz di pesantren. ${ }^{48}$

Senada dengan Agus Moh. Najib, Ust. Ahsan Ghazaly menuturkan sebagai berikut:

"Dulu ketika kita masih bersama-sama menjadi pengurus KESAN (Keluarga Santri Langitan), ketika ingin memutuskan masalah, pasti beliau mengajak para jajaran pengurus untuk bermusyawarah mufakat terlebih dahulu. Dan juga dulu kyai Masbuhin pernah meminta masukan serta pertimbangan kepada Masyayikh Langitan ketika beliau menghadapi permasalahan yang cukup besar dan sulit untuk diputuskan. Beliau sangat demokratis dalam memutuskan hal apapun." ${ }^{\prime 9}$

Menambahkan penjelasan dari Agus Moh. Najib dan Ustadz. Ahsan Ghazaly, Agus Muhammad Ma'ruf menjelaskan bahwa gaya kepemimpinan KH. Masbuhin Faqih adalah demokratis dan otoriter:

"Menurut saya, bapak adalah tipe pemimpin yang demokratis. Contohnya, dulu ketika terjadi silang pendapat antara beliau dengan putra-putri beliau tentang pembangunan pondok pesantren mana yang akan didahulukan, beliau selalu mengajak putra-putrinya untuk terus menyelesaikannya dengan musyawarah. Dengan jalan komunikasi yang intenlah akhirnya semuanya dapat disepakati. Namun tidak menutup kemungkinan bahwa beliau kadang-kadang juga menerapkan konsep otoriter. Contohnya, ketika beliau ingin mengutus putra-putranya untuk memimpin salah satu cabang pondok pesantren di daerah Gresik. Beliau secara tegas menyuruh H. Agus Suhaimi untuk menjadi pengasuh pesantren Mambaus Sholihin IV di Balongpanggang-Gresik, dan mengutus H. Agus Zainul Huda untuk menjadi pengasuh pesantren Mambaus Sholihin III di BenjengGresik. ${ }^{50}$

Senada dengan H. Agus Muhammad Ma'ruf, H. Hafidz menjelaskan bahwa kepemimpinan

KH. Masbuhin Faqih adalah demokratis dan otoriter.

"Mengenai kepemimpinan, beliau adalah seorang tipe pemimpin yang demokratis dan otoriter. Mengapa saya mengatakan demikian, karena memang sikap beliau dalam memutuskan perkara adalah sebagaimana yang saya katakan tadi. Contohnya beliau bersikap demokrtais, di setiap awal dan akhir tahun, beliau mengumpulkan ketua madrasah dari tiap lembaga untuk membahas program kerja atau rencana ke depan demi kemajuan pesantren. Sedangkan contoh dari sikap otoriter beliau adalah menyuruh seluruh santri untuk melaksanakan shalat malam (shalat tahajjud, hajat, witir dan lain-lain), serta hafalan imrithy atau maqshud untuk tingkat madrasah Tsanawiyah, dan menghafalkan nadzom Alfiyah.

48 Wawancara dengan Gus Moh. Najib (Menantu KH. Masbuhin Faqih)

${ }^{49}$ Wawancara dengan Ust. Ahsan Ghazaly (menantu KH. Abdullah Faqih Langitan-Tuban)

${ }^{50}$ Wawancara dengan H. Agus Muhammad Ma'ruf (Putra KH. Masbuhin Faqih) 
untuk tingkat madrasah Aliyah. Secara umum kepemimpinan beliau adalah demokratis, namun dalam hal tertentu beliau bersikap otoriter sebagaimana yang saya jelaskan di atas." ${ }^{51}$

Hasil analisis penulis dalam permasalahan ini bahwa apa yang telah dilakukan oleh KH. Masbuhin Faqih selaras dan serasi dengan teori Path-Goal yang dikembangkan oleh Robert House, yang menyatakan bahwa merupakan tugas seorang pemimpin untuk membantu anggotanya dalam mencapai tujuan mereka dan untuk memberi arah dan dukungan atau keduanya yang dibutuhkan untuk menjamin tujuan mereka sesuai dengan tujuan kelompok atau organisasi secara keseluruhan. ${ }^{52} \mathrm{Hal}$ ini tercermin seperti apa yang dijelaskan oleh $\mathrm{H}$. Hafidz, selaku kepala Madrasah Ibtidaiyah yang menerangkan bahwa beliau selalu memberi petuah atau nasehat untuk semua lembaga yang ada di pondok pesantren tiap awal dan akhir tahun. Hal ini bertujuan untuk evaluasi secara rutin agar harapan tiap-tiap lembaga yang ada di pesantren berbanding lurus dengan apa yang dikehendaki pengasuh pesantren. Sama halnya dengan H. Hafidz, Nikmatul Wahyuni selaku guru di RA Mambaus Sholihin juga menambahi keterangan bahwa KH. Masbuhin Faqih ketika rapat yayasan pasti memberi pengarahan atau semacam wejangan untuk kemajuan lembaga di pesantren. ${ }^{53}$

Dalam hal kepemimpinan, para kiai memiliki pola kepemimpinan yang berbeda antar satu kiai dengan kiai lainnya. Misalnya, Pondok Pesantren al-Falahiyah yang didirikan pada tahun 1963 oleh KH. Zamruddin dan Nyai Hajjah Rubai'ah adalah pondok pesantren putri pertama yang fokus pada bidang tahfidz al-Qur'an. Al-Falahiyah merupakan pondok pesantren ketiga yang di bangun di Mlangi setelah Pondok Pesantren Salafiyah dan Al-Miftah. Saat ini, pesantren tersebut diasuh oleh Muhammad Rifqi Aziz putra KH Zamruddin atau yang dikenal dengan sebutan Gus Rifqi. ${ }^{54}$

Apa yang disampaikan oleh Zainal Arifin di atas tentu sangatlah benar, karena memang setiap kiai memiliki gaya atau tipe kepemimpinan yang berbeda. Perbedaan gaya atau tipe kepemimpinan ini bisa dilatarbelakangi oleh factor bawaan maupun faktor ekologi. Oleh karena itu setiap kiai yang memiliki pesantren, pasti akan ada perbedaan dalam hal gaya atau pola kepemimpinannya. Tentu hal ini biasanya sangat berdampak pada perkembangan pondok pesantren. Oleh karena itu, menurut hemat penulis, sudah menjadi keniscayaan bahwa seorang pemimpin itu secara umum memiliki beberapa gaya atau tipe yang menjadi ciri khas atau kharakter yang dimilikinya.

\footnotetext{
51 Wawancara dengan H. Hafidz (Kepala MI Mambaus Sholihin)

52 Wawancara dengan H. Hafidz (Kepala MI Mambaus Sholihin)

53 Wawancara dengan Nikmatul Wahyuni (guru di RA Mambaus Sholihin)

${ }^{54}$ Zainal Arifin, "Kepemimpinan Kiai Dalam Ideologisasi Pemikiran Santri Di Pesantren-Pesantren Salafiyah Mlangi Yogyakarta" dalam (“INFERENSI" Jurnal Penelitian Sosial Keagamaan Vol. 9, No. 2, Desember 2015), 356.
} 
Hasil pembahasan ini menyatakan bahwa terkait gaya kepemimpinan di dalam pondok pesantren, KH. Masbuhin Faqih adalah sosok pemimpin yang demokratis, kharismatik dan kadang kala bisa berubah menjadi seorang pemimpin yang otoriter. Sebagai data tambahan, Seperti yang penulis ketahui selama menjadi santri di pondok pesantren Mambaus Sholihin dan sempat juga mengabdi sebagai tenaga pendidik di MTS dan madrasah diniyah Mambaus Sholihin, penulis menyimpulkan bahwa beliau KH. Masbuhin Faqih terkait gaya kepemimpinannya adalah seorang pemimpin yang kharismatik dan demokratis. Mengapa penulis katakan bahwa beliau seorang pemimpin yang kharismatik? Karena memang dari akhlak, sikap, jati diri, dan integritas beliau memang selalu tampak aura kharismatiknya. Ini yang kemudian menjadi faktor pendukung untuk mengelola dan mengembangkan pesantren, sebagai pendidikan Islam tertua di Indonesia.

Seorang kiai sebagai pemimpin pondok pesantren selalu identik dengan tipe kepemimpinan kharismatik. Seluruh warga lembaga pendidikan yang ia pimpin memiliki loyalitas yang sangat tinggi kepadanya. Dengan tipe kepemimpinan tersebut, pondok pesantren terbukti tidak pernah ditinggalkan oleh umat. ${ }^{55}$

Adapun gaya kepemipinan yang kedua menurut analisis penulis adalah beliau $\mathrm{KH}$. Masbuhin Faqih termasuk pemimpin yang demokratis. Hal ini selalu tergambarkan dalam setiap musyawarah, baik dalam level tiap lembaga pendidikan maupun pada saat musyawarah di sebuah peringatan acara. Penulis selalu melihat bahwa beliau dalam rapat, selalu meminta saran, ide atau pendapat kepada seluruh peserta rapat agar mendapatkan hasil mufakat yang disetujui secara bersama. Ini menandakan secara jelas bahwa beliau seorang pemimpin yang menjunjung tinggi asaz mufakat atau demokrasi, sehingga tak bisa disangkal bahwa beliau dalam gaya kepemimpinan termasuk memiliki gaya kepemimpinan yang demokratis.

Secara keseluruhan apa yang dilakukan oleh KH. Masbuhin Faqih dalam hal kepemimpinan ini adalah termasuk kategori pemimpin yang baik. Hal ini bisa dibuktikan dengan perangai beliau yang hangat, semangat, perhatian, disiplin, suka memotivasi santri serta tegas dalam berbagai hal. Gaya kepemimpinannya pun baik, karena beliau termasuk seorang pemimpin yang kharismatik, demokratis dan otoriter. Ini selaras dengan apa yang dikatakan oleh Bernard M. Bass bahwa seorang pemimpin yang dinilai baik menitikberatkan pada pemenuhan dan dukungan sebagai teknik motivasi dan bertindak dengan cara hangat serta membantu, menunjukkan perhatian dan penghargaan kepada bawahan. Sedangkan pemimpin yang buruk adalah yang memberi ancaman, merendahkan, berperilaku tanpa pertimbangan. ${ }^{56}$

\footnotetext{
55 Guntur Cahaya Kusuma, "Pesantren dan Kpemimpinan Kiai” dalam “TERAMPIL” Jurnal Pendidikan dan Pembelajaran Dasar Volume 1 Nomor 1 Juni 2014 p-ISSN 2355-1925, 110.

${ }^{56}$ R. Wayne Pace dan Don F. Faules, Komunikasi Organisasi (Bandung: Rosdakarya, 2018), 280.
} 


\section{Penutup}

Pesantren adalah lembaga pendidikan yang tidak bisa dipisahkan dari figur seorang kyai sebagai pemimpinnya. Kemajuan atau kemunduran sebuah pesantren banyak ditentukan oleh peran kyai sebagai figur sentral di pesantren. Dengan demikian, pesantren dan kyai mempunyai hubungan yang saling mempengaruhi. Pesantren bisa berkembang karena sosok kyainya yang bisa memimpin dengan baik. Sebaliknya, pesantren tidak berkembangan karena sosok kyainya yang tidak bisa memimpin dengan baik, meskipun ini jumlahnya sedikit.

Dalam hal gaya kepemimpinan, dari hasil wawancara, observasi dan analisis data, dapat disimpulkan bahwa gaya kepemimpinan KH. Masbuhin Faqih, pengasuh pondok pesantren Mambaus Sholihin Gresik adalah termasuk pemimpin yang kharismatik, demokratis dan otoriter di lain waktu.

Oleh karena itu kepemimpinan sangatlah penting dan perlu untuk dicermati bagi semua kiai yang ada di seluruh pelosok negeri ini agar dalam pengelolaan pondok pesantren dapat berjalan secara baik, istiqomah dan selalu menjaga integritas dan khazanah keilmuannya sebagai ciri khas sebuah lembaga pendidikan Islam.

\section{Daftar Kepustakaan}

Ahmad Hasyim, Sayyid. Mubtar al-Hadits an-Nabawiyyah, Jakarta: al Haramain Jaya Indonesia, 2005.

Arif, M. Khoirul. Manajemen Pesantren, Yogyakarta: Pustaka Pesantren, 2005.

Arifin, Zainal. "Kepemimpinan Kiai Dalam Ideologisasi Pemikiran Santri Di Pesantren-Pesantren Salafiyah Mlangi Yogyakarta” dalam "INFERENSI” Jurnal Penelitian Sosial Keagamaan Vol. 9, No. 2, Desember (2015)

Cahaya Kusuma, Guntur. "Pesantren dan Kepemimpinan Kiai” dalam "TERAMPIL" Jurnal Pendidikan dan Pembelajaran Dasar Volume 1 Nomor 1 Juni 2014 p-ISSN 2355-1925.

Chalik, Abdul. Kiprah Tradisionalis Yang Tersisih, Yogyakarta: Inter Pena, 2011.

Chayyi, Abd Fanany. Pesantren Anak Jalanan, Surabaya: Alpha, 2008.

Djarkasih, Organisasi, Jakarta: PT. Gelora Aksara Pratama, 1997.

Dhofier, Zamakhsyari. Tradisi Pesantren: Studi Tentang Pandangan Hidup Kiai, Jakarta: LP3ES, 1982.

Hajar, Ibnu. KIAI di Tengah Pusaran Politik antara Petaka dan Kuasa, Jogjakarta :IRCiSoD, 2009.

Halida, Prinsip-Prinsip Perilaku Organisasi, Jakarta: PT. Gelora Aksara Pratama, 1999.

Hasibuan, Malayu S.P. Manajemen, Jakarta: Bumi Aksara, 2005.

Imron, Arifin. Penelitian Kualitatif, Malang: Kalimadasa Pers, 1996.

Karim, Muhammad, Pemimpin Transformatif di Lembaga Pendidikan Islam, Malang: UIN-Maliki Press, 2010. 
Kementrian Agama RI, al-Qur'an dan Terjemahnya, Jakarta : PT. Lentera Abadi, 2010.

Krisdianto, Gatot. Muflikha, Muflikha, Elly Elvina Sahara, Choirul Mahfud, "Sistem Pendidikan Pesantren dan Tantangan Modernitas”. Tarbawi: Jurnal Ilmu Pendidikan, Vol. 15 Nomor 1 (July 2019), 11-21.

Masyhud, M. Sulthon dan Moh. Khusnuridlo, Manajemen Pondok Pesantren, Jakarta: Diva Pustaka Press, 2005.

, Manajemen Pondok Pesantren Dalam Perspektif Global, Yogyakarta: LaksBang PRESSindo, 2006.

Pace, R. Wayne dan Don F. Faules, Komunikasi Organisasi, Bandung: Rosdakarya, 2018.

Riyanto, Metodologi Penelitian: Suatu Tinjanan Dasar, Surabaya: SIC, 2001.

Rivai, Veithzal. Pemimpin dan Kepemimpinan dalam Organisasi, Jakarta: PT Raja Grafindo Persada, 2005.

Siagian, Sondang P. Teori dan Praktek Kepemimpinan, Jakarta: PT. Rineka Cipta, 1994.

Sukamto, Kepemimpinan Kiai dalam Pesantren, Jakarta: LP3ES. 1999.

Tampubolon, Manahan P. Perilaku Keorganisasian, Bogor: Ghalia Indonesia, 2004.

Undang-Undang R.I. Nomor 20 Tahun 2003 Tentang Metode Pendidikan Nasional dan Peraturan Pemerintah R.I. Tahun 2010 Tentang Penyelenggaraan Pendidikan serta Wajib Belajar, Bandung: Citra Umbara, 2012.

Uha, Ismail Nawawi, Perilaku Organisasi, Jakarta: CV. Dwiputra Pustaka Jaya, 2010.

Winardi, Kepemimpinan dalam Manajemen, Jakarta: PT Rineka Cipta, 1990.

Zaini Hafidh, Badrudin "Pesantren dan Kemandirian Perekonomian: Studi tentang Kewirausahaan di Pondok Pesantren Ar-Risalab Cijantung IV Ciamis dalam "Manageria: Jurnal Manajemen Pendidikan Islam” Volume 3, Nomor 2, November 2018/1440.

Dokumentasi Pondok Pesantren Mambaus Sholihin Gresik 